\title{
Stigma, Trauma and the Social Forces Shaping Memory Transmission in Argentina
}

\author{
Jill Stockwell, Swinburne University
}

Since the return to democratic rule in Argentina in 1983, competing claims about how the period of political and state violence of the 1970s and 1980s might be collectively remembered by the nation have caused deep political and societal divisions. This paper explores the personal memories of Argentine women ${ }^{1}$ from two ideologically-opposed groups - those on the political Left affected by military repression during the 19761983 military dictatorship and those on the political Right affected by the armed guerrilla violence predominantly in the years leading up to the 1976 military coup. ${ }^{2}$ In contemporary Argentina, the memories of enduring personal trauma carried by both groups of women are commonly perceived as unable to co-exist in a shared mnemonic

\footnotetext{
${ }^{1}$ Women have played and continue to play a highly visible and active role in Argentine memorial cultures, and are particularly influential in the intergenerational transmission of memories. Despite women playing a central role in the transmission of memory to the next generation, in many transitional contexts the role women play is marginalised. In Argentina, however, there is a direct connection between women remembering experiences of violence at a grassroots level and their attempt to gain a place in the public sphere. I suggest that we can learn a great deal from looking at how Argentine women have mediated and assimilated their traumatic pasts, both publicly and privately, as well as the ways in which their practices of remembrance impact and shape social relations, and apply these to better understanding women's experiences of violence in other transitional contexts.

${ }^{2}$ In the years leading up to the military coup, political violence was widespread (Calvero 2005). There were armed groups on various sides of the ideological divide, including an armed guerrilla movement (extreme Left) and paramilitary death-squads (extreme Right). The guerrilla groups were engaged in urban bombings that claimed scores of victims and mounted attempts on military installations and their personnel (Brysk 1994). The Peronist Montoneros and the Marxist Ejército Revolucionario del Pueblo (ERP) were considered to be the two main armed guerrilla groups.
}

PORTAL Journal of Multidisciplinary International Studies, vol. 11, no. 1, January 2014. Stigma and Exclusion in Cross-Cultural Contexts Special Issue, guest edited by Annie Pohlman, Sol Rojas-Lizana and Maryam Jamarani.

ISSN: 1449-2490; http://epress.lib.uts.edu.au/ojs/index.php/portal PORTAL is published under the auspices of UTSePress, Sydney, Australia. 
space-as if remembering one history of violence is seen as an attempt to forget or violate the other history of violence and trauma.

Vittoria Villaruel, who works on behalf of the victims of the armed guerrilla movement, told me of the public hostility and harassment faced by the families she supports on a daily basis. In our interview, she told me that she herself has publicly been labelled a fascist for demanding human rights on behalf of the organisation's victims. 'We're being called Nazis for defending innocent people,' Vittoria told me. ${ }^{3}$ Her observation made me realise that despite pioneering many of the justice-seeking and truth-telling mechanisms designed to 'deal with’ the past in transitioning democracies, Argentine memorial cultures remain in the entrenched political and ideological divisions of old.

I contend that we need to look beyond political and ideological contestations and engage in a deeper analysis of how memorial cultures are created and sustained. I argue that we cannot account for the antagonism and stigma pervading Argentine memorial cultures, without acknowledging the role played by individual emotions and affect in generating and shaping collective emotions and affects (Hutchison \& Bleiker 2008). ${ }^{4} \mathrm{I}$ am not attempting to depoliticise the conversation about memory and trauma in contemporary Argentina; nor am I seeking to deny that the two groups exist in a heavily politicised arena. However, I am proposing that we shift our attention away from the exclusive focus on the political and ideological nature of their stories of violence and incorporate an affective reading of the two groups of women's traumatic memories.

In this paper, I explore the role of the transmission of emotions and affects with regard to how and why they can stir individuals and collectives to such an extent that the past continues to operate as a source of social and political division. Drawing on

\footnotetext{
${ }^{3}$ Interview with Vittoria Villaruel, Director, El Centro de Estudios Legales Sobre el Terrorismo y sus Victimas (CELTYV), Buenos Aires, 29 April 2009. The research for this paper is based on oral testimonies I collected in 2009 in Argentina as part of my $\mathrm{PhD}$ research with two groups of women: those whose family members were kidnapped and murdered by the armed political groups from 1973 to 1976; and those whose family members were kidnapped, disappeared or murdered by the military government from 1976 to 1983. The interviewees emphasised their preference for disclosing both their names and the identities of their missing/killed family members. All translations of the women's quotes are my own.

${ }^{4}$ Affect can be used as a broad term to refer to emotions, feelings, and affects (Shouse 2005: para 2). The three terms are often used interchangeably. Feelings are personal and biographical, emotions are social and affects are pre-personal (para 2). Displays of emotion can be genuine or feigned; when we relay our emotions publicly, they may be an expression of our internal state or they may be contrived in order to fulfil social expectations (para 4). Affects are more abstract than emotions because they cannot always be fully realised in language (para 5). They are non-conscious and unformed, and refer to the body's way of preparing itself for action in a given circumstance with an added dimension of intensity (para 5).
} 
contemporary theories of the emotional and affective transmission of memories, I consider the verbal and non-verbal ways in which traumatic memories are communicated between individuals. ${ }^{5}$ In analysing the affective transmission of memory, I seek to develop ways of thinking about how emotions and affects can shape encounters between people and permeate public spheres of remembrance. Rather than simply rendering a factual narrative of the past, this paper engages emotions and affects as a way of exploring how these may become the source of a different kind of understanding of the stigma that fuels existing societal antagonisms in Argentine society.

\section{The politics of remembering in Argentina}

Argentine scholar Elizabeth Jelin (2003) suggests that every time Argentina experiences a change of government debates surface over what and how to remember the period of repression and political violence in the 1970s and 1980s. Various actors who have taken part in these debates have linked their political programs for the future with the memories of a violent past (Jelin 2003). As a result, the two different groups of victims - those of the Left versus those of the Right - have come to view the public sphere in which they articulate their memories of trauma as a 'scarce resource' (Rothberg 2009: 3). It is as if different memories vie for pre-eminence in a constant struggle for political, social and legal recognition in which (again) there are only winners and losers (Rothberg 2009).

As political opponents have pushed to remember certain groups of victims while sidelining others within the formation of Argentina's collective memorial culture, contentious debates about past violence within society have intensified. These debates have resulted in the polarisation of groups that struggle to overcome the injustices of political recognition over whose history should ultimately be recognised. These competitive ideological battles have had major consequences for the make-up of the public sphere in which individual memories enter and circulate in the present day; they have also had crucial implications for the shaping of Argentine collective memorial culture and identity. With an increasing need for collective identity amidst social and political conflicts over how to account for violations experienced during this traumatic

\footnotetext{
${ }^{5}$ Maurice Halbwachs (1992) originally asserted that rather than residing within the individual memories are formed and organised within a collective context; as a result various groups of people have different collective memories, which in turn give rise to different modes of behaviour. In other words, Halbwachs believes that the memory of individuals is influenced by the social context in which they function and that virtually all experiences and perceptions are shaped by one individual's interaction with another.
} 
past, Argentina has developed into a society of memory groups, with each claiming recognition and the legitimacy of its voices and demands. As those who personally experienced suffering have given oral testimony in the public sphere and talked of their experiences with others, memory has become a common language through which individuals have been able to articulate and share their traumatic experiences. As a result, memory has become a dominant form of belonging in Argentina.

Members of particular political and ideological groups have created a shared fabric of a life-world in which remembering their loved ones who were affected by political and state violence is central. The spread of these community-based groups, whereby being a group member means assuming a shared identity and subscribing to a shared group past, has resulted in the 'problematisation of memory' (Misztal 2004: 68). As the boundaries of memory parallel the boundaries of group identity, there is a sense of competitive victimhood as groups compete for the recognition and legitimisation of their memories of victimhood at the exclusion of others within the public sphere (Rothberg 2009).

There has been a long history to reclamation rights in Argentina since the end of military rule. However, official recognition of the desaparecidos ${ }^{6}$ only came about after 2003. Néstor Kirchner - the first Peronist President since the successive administrations of Juan and Isabel Péron prior to the military coup of 1976 — came to power in that year and endorsed new cultural models of collective remembrance. For the first time since the early days of the return to democratic rule, the governments of Néstor Kirchner (2003-2007) and Cristina Fernández Kirchner (since 2007) embraced the traditional discourse of human rights by consecrating the idea of memory as a 'national duty' (Sosa 2009: 251). Following years of being publicly stigmatised and questioned about their individual involvement in armed guerrilla activities, and dealing with consistent institutional denial—particularly under the Menem government ${ }^{7}$ — survivors and

\footnotetext{
${ }^{6}$ Coined by the military as a way of denying the kidnap, torture and murder of its citizens, the word desaparecer, 'to disappear,' began to be used as a transitive verb in the Argentine language from the time of the military coup, 24 March 1976 (Feitlowitz 1998). Those who were disappeared by the Argentine military are referred to as los desaparecidos; the majority were abducted by the security forces and taken to clandestine detention centres, where they were tortured and later murdered (CONADEP 1986). The total number of disappeared is contested. Argentina's Under Secretariat for Human Rights estimates the official number of disappeared to be up to 12,000 (Barahona de Brito et al. 2001). Thirty thousand is considered an emblematic figure used by many Argentine human rights organisations.

${ }^{7}$ When Carlos Menem assumed office in July 1989, he extended pardons to all military officials with human rights prosecutions pending and to former military junta leaders already convicted of human rights violations (Brysk 1994).
} 
families of the desaparecidos finally felt they were being acknowledged under the Kirchner administrations.

In recent times, however, the families of victims of the armed guerrilla movement have rallied together to fight against perceived moves by the current government to remember one side of history while forgetting the other. These families told me that their feelings of victimisation had been reignited since the Kirchner administrations took office. In their view, the Kirchners began to make the memories of loss and violence of the families of the desaparecidos more politically relevant than those of the families of the victims of the armed guerrilla movement.

For example, Lorenza told me of her struggle to find a reason to keep on living because the sadness and the sense of loss she experienced on a daily basis were overwhelming. She told me that the memory of seeing her only daughter, nineteen-year-old Laura, critically wounded by a car bomb that exploded outside the gates of her university in 1975, never leaves her. Lorenza described feeling as though she is forced to exist on the edge of society, in a no-man's land, because her daughter Laura, who was apolitical, was in the wrong place at the wrong time when a car bomb that was planted by the armed guerrilla movement exploded. She told me: 'These were political ideas that weren't mine, that weren't of my family, that weren't of Laura. And we were victims of these political ideas.' For Lorenza the struggle she has faced to live with such traumatic memories has been compounded by a sense of ‘imposed oblivion’ (Passerini 2003: 247) and a never-ending struggle for the moral and legal recognition of her memories in the public sphere. Lorenza told me that she sent three letters to the President of Argentina, asking for those responsible in the armed guerrilla movement to be held legally accountable. She received no reply but, many months later, was deeply confused when she was sent a card from the President wishing her a 'Happy New Year.' Lorenza reveals the extent to which she is locked psychically into the dependence on the state for recognition of her traumatic memories. She continues:

I have never received an explanation [of who killed Laura]. I can never receive an explanation when there's so much silence and so much forgetfulness. The pain I feel is already bad enough but this is what makes my pain so much worse. Completely ... Terror touched me. And this, I don't know, is abandoning someone, really abandoning someone. ${ }^{8}$

\footnotetext{
${ }^{8}$ Interview with Lorenza Ferrari, Buenos Aires, 29 July 2009.
} 


\section{Vittoria Villaruel from El Centro de Estudios Legales Sobre el Terrorismo y sus}

Víctimas (CELTYV) ${ }^{9}$ stressed that the organisation had initiated thousands of lawsuits over recent years. Many of the families feel they have been denied justice because the state, while having an obligation to investigate the claims, has refused to do so. Lorenza concurs:

In recent years [I feel the injustice] a lot more. Before there was always a little hope, that there would be more justice. But now, I despair that there could ever be justice. Today, and today more than yesterday, and for certain tomorrow more than today, I ask for justice. I want to know why ... For me, every day, when I hear the difference that is being made between the dead, it's like being stabbed [in my heart]. It's like being stabbed because it's another foot that is pushing Laura into the ground ... Justice is blindfolded. Justice is blind [in Argentina] because it doesn't see that which it should.

Rather than playing a role in expanding social patterns of recognition, Lorenza perceives the current government's political approach to collective remembrance of the period of political violence during the 1970s has magnified the social and cultural conditions that foster feelings of marginalisation, ostracism, resistance and anger among the families of victims of the armed guerrilla resistance. Lorenza told me she has sought support from the organisation CELTYV, not because she has ever been affiliated in any way with the political Right, but because her daughter was killed in an attack by the armed guerrilla movement. With the current government uninterested in her claim for recognition, she feels she has nowhere else to turn for support. Though not affiliated with the political Left or Right, Lorenza still finds herself caught up in the middle of competitive remembering. Her story shows how someone who is apolitical can be coopted into a political discourse because they have nowhere else to turn. Lorenza was angry because she was ostracised by Argentine society simply because her daughter was killed by 'the wrong crowd.' She told me:

Today I know there are Montoneros still alive, some of whom, I want to tell you clearly because I have nothing to hide ... if I have something to say I will say it ... some of them are in today's government. As a political idea, I'm not saying they were Laura's killers, but as a political idea, they are in government and they are the same ones who won't acknowledge what happened to me and to others. That's to say, the military have someone to defend them, the Montoneros have someone to defend them. But who's going to defend me? Me, my son, my husband, nobody has come near us; no government has ever looked after our mental health because I'll tell you, insanity is waiting at the door. It only has to open it.

\footnotetext{
${ }^{9}$ The organisation offers psychological support to the victims of the armed guerrilla movement, and runs publicity campaigns to heighten awareness, both locally and internationally. It also prepares cases and campaigns the government to reopen legal proceedings against those suspected of the murder of the family members that the organisation represents. The organisation, though concerned with issues of historical justice, is perceived by the Argentine human rights movement as having an active political agenda.
} 
Women such as Lorenza regularly give oral testimony in the public sphere as a way of countering the 'amnesia' imposed by various societal and institutional groups around past injustices. Only by testifying to their traumatic experiences do the women with whom I spoke feel they can 'reinscribe their subjectivity into situations that mutilated it to the point of annihilation' (Oliver 2001: 99). However, in doing this they face the prospect that their testimonies could be forever 'on trial,' their credibility constantly questioned (99). This is true for any testimony that ascribes to forms of oppression, argues Oliver (2001), so long as the culture within which an individual speaks continues with policies of amnesia. Despite this, the two groups of women continue to give oral testimony as a way of justifying their status as fully fledged citizens of Argentine society, flying in the face of any attempts to silence the memories of their loved ones.

\section{The transmission of emotions}

Powerful collective memories about the period of state terror and political violence of the 1970s and 1980s have heightened political and social tensions in contemporary Argentina. In turn, strong bonds have been formed between individuals from within adversarial memorial cultures, resulting in highly specific collective memories. Much of the power of these collective memories, I argue, has in part been derived from the strong emotions that they provoke. For memory belongs in the 'intermediary realm' between individuals; it develops and grows out of the interplay of interpersonal relations and, as such, the emotions play an important role in this process (Assmann 2006: 3).

Oral testimony has played a crucial role in how events have collectively been assimilated and remembered in Argentina. In continuously speaking publicly about their traumatic memories and relating their emotional experiences in the form of oral testimony, the women I interviewed have thus played a significant role in an important social psychological process called the 'social sharing of emotions’ (Rimé \& Christophe 1997: 133). There is much empirical evidence suggesting that emotions tend to be socially shared (Rimé \& Christophe 1997). While researchers previously considered emotions as merely a short-lived and intrapersonal phenomenon, more recent theories on emotions reveal strong evidence that emotions are essentially interpersonal communicative acts, which instead involve long-term social processes: the more individuals are upset, the more likely they are to share their story with others and to elicit vivid and long-lasting memories of the event (Rimé \& Christophe 1997). This process can influence the way 
an historical experience is organised in memory and perhaps recalled in the future (Pennebaker \& Banasik 1997).

I suggest that the social sharing of emotion has contributed significantly to the ongoing polarisation between the Right and Left within Argentine collective memorial culture as individuals' perceptions and understanding of violent events have been shaped by those giving oral testimony. The fear and terror associated with past violence are strongly communicated by both groups of women in their narratives, and this in turn can engender strong feelings in those listening. For example, Gladys, whose military husband was killed by the armed guerrilla movement in 1976, reiterated negationist information that she had received through others about the 'real' fate of the desaparecidos:

The children that they [human rights organisations/families of the disappeared] say are disappeared ... you can't believe that it's true. Some friends of mine went to see the names listed on the posters [of Las Madres] in the Plaza de Mayo and they know for a fact that they are alive. So it's not certain ... it's not certain. ${ }^{10}$

Gladys is visibly angry as she reconstructs and shares with me negationist claims that she has received from others within her memorial group. It is information that serves to create a doubt about the fate of those who were disappeared by the military. As Gladys circulates the information, her emotional experience also circulates and spreads throughout her social group. Therefore, as individuals repetitively relate their emotional experiences to others, the social group gradually assimilates those experiences and, as a result, is furnished with new emotional knowledge (Rimé \& Christophe 1997). As we can see from Gladys's narrative, as the two groups of women share memories about their traumatic life events in the public sphere, the attitudes of those listening can also become more extreme toward past collective issues and the current society (Paez, Basabe \& Gonsalez 1997).

In going beyond the women's standard narratives of trauma and violence, and in exploring the transmission of their emotions, we can see how the women have 'an ability to affect and be affected' when they talk about their shared pasts (Massumi 1987: $\mathrm{xvi})$. I argue that the women's emotions are a social force that remains and is at work in the public sphere long after they have shared their experiences with others. I suggest that the women's emotions leave an affective residue, which has what Anna Gibbs

\footnotetext{
${ }^{10}$ Interview with Gladys Echegoyen, Buenos Aires, 22 July 2009.
} 
(2010: 187) describes as an 'energetic capacity.' This capacity contributes toward a sense of the continuance of stigma and animosity over time. The affective residue helps to sustain and preserve the connections between those ideas, thoughts, values and habits that act as an affective charge within a politics of remembering in contemporary Argentine society.

\section{The transmission of affects}

Though not always visible or noticed, I argue that powerful affects are also released in the process of individuals remembering and sharing their traumatic pasts. Like the emotions, affect is another social force that structures group identities, and the traffic between the individual and collective forms of remembrance. Affect also plays a role in what Stern calls 'the interpersonal traffic of feeling’ (cited in Watkins 2010: 278). Affect is the name we give to those forces that can serve as a kind of 'raw psychic material' to drive us towards movement and thought, and influence our conscious and unconscious behaviours and attitudes (Tumarkin 2009: 8).

Affect cannot be fully realised in language, as it is always prior to or in excess of conscious states of perception (Massumi 2002). It has a grammar of its own, and is the body's way of preparing it for action and reaction in a given environment at a certain level of intensity (Massumi 2002). Massumi (2002) defines affect in terms of its autonomy from conscious perception and language; it is about the body opening up to the indeterminacy of its automatic responses. Gilles Deleuze's work on corporeality suggests the ways in which affect is mediated through the dynamic interaction between different bodies: 'A body affects other bodies, or is affected by other bodies; it is this capacity for affecting and being affected that also defines a body in its individuality’ (1988: 123). Deleuze's theory challenges assumptions about the boundaries and the boundedness of bodies, or 'what we take to be our own and how one body relates to others' in its vicinity (Probyn 2010: 76).

We can apply Deleuze's model of bodily affect to contemporary Argentina as a way of understanding how the fear lodged deep inside the mental space of Argentine civilians by the military government persists and circulates in non-verbal and nonrepresentational ways among individuals and throughout the society today. In our interview, Abuela Buscarita and Abuela Raquel told me that a well-known clandestine detention centre used by the military to torture the desaparecidos was located around 
the corner from Las Abuelas's head office. They avoid passing by the centre because it induces so much fear and anxiety within them—so much so that it can raise the hair on their skin. The women know that, historically, the building holds within it a level of danger; they already have an impression of the risks associated with the building and this impression is felt on the surface of their skin (Ahmed 2004a). The fear and anxiety is exacerbated as the Abuelas pass by the building because they are physically reminded of their deep losses, and this anxiety is displaced on to the object of their fear (Ahmed 2004a): the detention centre. As a result, fear shapes the borders between the Abuelas and the building, as they affectively grasp that it is a danger that should be avoided.

Deleuze's understanding of the ability of bodies to affect and to be affected provides a powerful way of understanding how the women's feelings of loss, melancholy and anger when remembering their traumatic pasts can accumulate, seep into and reside within other bodies in the public sphere, altering individuals' understanding of their selves as well as their relation with the past (Probyn 2010). Going public with their narratives ensures that testimony occupies a public sphere, which can include both identifiable witnesses as well as potential addressees (Rothberg 2008). In this way, the circulation of the women's narratives and the accompanying affects result in the shaping of the contours of the public space they inhabit (Rothberg 2008). Their public testimonies fill this space with 'the psychic and physical losses that cannot be transcended' (Rothberg 2008: 219).

If we think about Deleuze's explanation of how affect works, then we are able to consider what this process of remembering may produce in the context of postdictatorship Argentina. Exploring how affect is retained and accumulated, and the way in which it can circulate between bodies and shape subjectivities, is crucial to our understanding of how it can form and mobilise individuals or groups in different ways over a period of time. ${ }^{11}$

\section{Transmission of affect and perception}

Laura speaks about how the attitudes and experiences of her parents have been crucial in shaping the fear of violence of the next generation of Argentines. She says:

\footnotetext{
${ }^{11}$ For further discussion on the emotional and affective transmission of trauma, see Stockwell (2014).
} 
[Some kids] were breastfed with fear. If a kid lives in a home where her parents are terrified and don't go out at night, she feels those things. There were parents who were always afraid during the military regime. They couldn't live a quiet life, scared that '[the military] would come and take us away.’ When you live in fear, you transmit this to your children. (cited in Kaiser 2005b: 56)

A number of scholars (Brennan 2004; Probyn 2005) suggest that affects can be contagious. Teresa Brennan's The Transmission of Affect (2004) develops this idea in her model of connectedness and transmission of affects. She asks: 'is there anyone who has not, at least once, walked into a room and "felt the atmosphere?”' (2004: 1). Brennan's idea also forms part of the intellectual history of crowd psychology and the sociology of emotion, and explains that we are not self-contained in terms of our energies; there is no clear boundary separating individuals and their environment. Brennan suggests that it is primarily a modern and Western approach to assume that the individual is energetically self-contained, and that affects and feelings are an individual's alone.

For Brennan the origin of transmitted affects is social, since affects can arise from within an individual but can also occur as a result of an interaction between an individual and his/her environment: 'By the transmission of affect, I mean simply that the emotions or affects of one person, and the enhancing or depressing energies these affects entail, can enter into another' (2004: 3). This, she contends, does not mean that an individual's particular emotional experience is irrelevant. Instead, Brennan points out that if one picks up on another's feelings or emotions, the thoughts one attaches to that affect remain one's own: 'they remain the product of the particular historical conjunction of worlds and experiences I represent. The thoughts are not necessarily tied to the affects they appear to evoke. One may as well say that the affects evoke the thoughts' (2004: 7). We can see in Gladys's example how the doubt spread among other members of her memorial group leads her to openly and publicly doubt the claims of Las Madres de la Plaza de Mayo and the human rights movement in her narrative.

I suggest that we look to theories of affect contagion as a way of understanding the role affects may play in the constitution of a relationship between individuals, groups and communities. In her model of the sociality of emotions, Sara Ahmed (2004a) argues that emotions create 'surfaces and boundaries' that assist individuals to discern between what is inside and outside in the first place. She believes that surfaces and boundaries are made precisely through the emotions, or through how individuals respond to objects, situations 
or others (Ahmed 2004a). ${ }^{12}$ In exploring the sociality of affects, we can begin to understand how affects work to align some individuals with some and against others. Ahmed's theory of affective attachment in particular gives us a way of understanding how emotions play a crucial role in the 'surfacing of individual and collective bodies' (2004a: 25). How we feel about others is what aligns us with a collective (Ahmed 2004a). Ahmed's theory offers a way to talk about both emotions and affect, and the ways in which both can shape individual and group perception.

Emotions and affects align individuals with communities through an intensity of attachment; in other words, those ideas that connect us to one thing or another, that which makes us feel or that which holds us in place (Ahmed 2000). In this way, the forming of the individual and the nation arises partly by viewing the 'other' as the cause of one's emotional duress (Ahmed 2004a). Through being moved by the proximity of another affective attachments take place, affecting some differently from others (Ahmed 2004a). For example, when the group Las Abuelas de la Plaza de Mayo (the Grandmothers) was nominated to receive the Nobel Peace Prize, an email petition was circulated by CELTYV asking for signatures in protest at the nomination of Las Abuelas. The petition declared that Las Abuelas had never spoken out in support of the victims of the armed guerrilla movement, and was in fact associated with those guerrillas who had killed their family members. The petition, to date with nearly 22,000 signatures, was sent to the Nobel Prize committee citing opposition based on the following rationale:

The families of the victims of terror have never heard, in 26 years of democratic rule, one word of consolation or empathy from members of an organisation [Las Abuelas] which supports the impunity of terrorists, a unilateral version of history, and the actions and disappearance of the collective memory of thousands of innocent victims of bomb attacks, kidnappings, torture, assassinations, and robberies, all left unpunished. (www.petitiononline.com/celtyv1a/petition)

Such a narrative produces a polarisation between the two groups of victims, and sets up an 'us' versus 'them' dichotomy that blames Las Abuelas for destroying any future possibility for peace and reconciliation in Argentina. The online petition reveals the existence of a perceived injury: the refusal of Las Abuelas to negate the violence committed by the armed guerrilla movement is constituted as the cause of CELTYV's members’ ongoing feelings of pain. CELTYV feels it is the injured party - the one that

\footnotetext{
${ }^{12}$ Ahmed (2004b) uses the term 'object' to refer to objects, situations or individuals.
} 
is hurt by the silence of Las Abuelas. It perceives this silence as a direct provocation, and holds Las Abuelas accountable for putting the well-being of the nation at risk.

One's perception of another involves a form of 'contact' between the individual and the 'other' that is shaped by longer histories of contact (Ahmed 2004b: 194). It is the 'moment of contact,' shaped and informed by past histories, which allows the proximity of the 'other' to thus be perceived as threatening. In this way, we can see how affects work to secure collectives through the way they align some individuals together, but against others (Ahmed 2004a). In the example of the online petition, hatred plays a role in shaping collectives by way of sustaining injured parties that adopt defensive approaches against those whose proximity is perceived as threatening. CELTYV feels victimised by Las Abuelas in the present because the organisation is seen as fighting for the memory of those who killed their family members.

The intensity of attachment the women feel for the 'other' has been shaped by the changing political approaches to collective remembering in Argentina since the return to democratic rule. As a result, the affective responses the women have towards their traumatic memories are partly triggered by the collective political approach to memorialisation in Argentina (Traverso 2010: 182). This point was articulated by Gladys, who expressed her growing despair with what she perceived as the current government's 'protection' of human rights groups within Argentina. These groups, Gladys believes, shelter those who committed crimes within the armed guerrilla movement, including those who killed her husband. She told me: 'I've never met them [Las Madres de la Plaza de Mayo], but it makes me mad because they appear with their posters, they are totally protected by this government.'

Paloma Aguilar Fernández suggests that: ‘One tends to see one’s contemporary adversaries through the prism of the adversary that one had in the past' (cited in Jelin 2003: 147). Gladys was confused by the different messages she had received, and mistrustful of some of the claims made by the families of the desaparecidos because of her association with them as mothers of 'terrorists' in the past. Gladys's example illustrates the vexed relationship in Argentina between the changing politics of remembrance, stigma and affect. 
As individuals, we become aware of ourselves through our contact with others (Merleau-Ponty 1962). This contact can generate both positive and negative affects. Power relations have a particular impact on the alignment between individuals when soliciting the recognition of others becomes a measure for the acknowledgement and confirmation of an individual's self-worth. When recognition functions in a negative way and carries with it the resultant force of negative affects, it can have a detrimental effect on an individual's self-worth. The ability of affect to accumulate and its relationship to recognition-and the ways in which this interconnected process may obliterate the possibility for empathic alignment with others — can be seen in the following example of the adversarial nature of interactions between different memorial cultures in Argentina.

In our interview, Barbara told me that to talk about her father is to recuperate his memory. As she was only very young when her father was killed, Barbara has relied on newspaper cuttings and anecdotes from her father's colleagues to understand who her father really was. The role her journalist father played in the violence of the 1970s before his death—unsolved in her mind—can be a source of intense frustration. 'He never killed anyone, I’m sure of it,' Barbara told me. She continued:

\footnotetext{
Where is the proof? ... The situation was very violent. He [her father] had a weekly television program where ... Tarquini [her father's name] was an easy target. Everyone in the world knew it because he was a very straightforward type, very energetic, and he talked very ... he said some very heavy things and in a strong way. My mother said that she knew that he was going to be killed ... because he was very honest, spontaneous ... there were times ... he was an exhibitionist. $^{13}$
}

Barbara describes her internal anguish at the lack of evidence provided by those attempting to vilify her father as a member of a right-wing paramilitary group, and the frustration she has suffered when her efforts to clear her father's name have been thwarted. Barbara struggles with feelings of stigmatisation and public shame because of the presumed role her father played in the terror inflicted by the military. Her story illustrates the way in which our perception of something as beneficial or harmful depends on how it affects us (Ahmed 2004b). Because of her interface with political and social judgements about the actions of her father in the past, Barbara feels ashamed that she herself has done something wrong; she feels that she is to blame in some way for her father's actions. Current political and social conditions produce within Barbara an

\footnotetext{
${ }^{13}$ Interview with Barbara Tarquini, Buenos Aires, 17 July 2009.
} 
ambiguous coexistence between feelings of shame and pride. She carries these contradictory emotions within herself, experiencing great anxiety at being unable to restore her father's memory in the public sphere and attain a sense of pride about who she is.

In Barbara's case, she has failed to elicit for herself a sense of social recognition. As Honneth explains: 'Recognition itself must possess the character of affective approval or encouragement' (1995: 95). These affects, states Watkins, 'are the corporeal instantiation of recognition, the sensations one may feel in being recognized, which accumulate over time, fostering a sense of self-worth’ (2010: 273). Moments of recognition therefore function as an affective force (Watkins 2010). Barbara's perception that political, social and cultural recognition is withheld from her when she remembers her father creates feelings of having failed in the eyes of the 'ideal other' (Ahmed 2004b).

For Barbara, recognition functions in a negative way, and carries with it the resultant force of negative affects. Barbara's sense of shame and her shattered sense of self-worth bind her negatively to others in her failure to 'live up to’ others (Ahmed 2004b: 107). Barbara has the impression that the government and human rights organisations are marginalising her personal memories of her father; moreover, those groups also leave her with the impression that she has something to feel shameful about. She feels that she cannot be a legitimate player in Argentina’s collective memorial culture.

\section{Severed social bonds}

When considering the physical, emotional and psychological damage that the women I interviewed have endured, it is not just the effects of trauma on an individual's bodily or 'skin' surface that we need to think about, but also the ways in which the 'skin' of the community has been affected (Ahmed 2004a). For example, the violence experienced during the 1970s and 1980s was not just inflicted on the bodies of those individuals who personally lived through the terror, but was also inflicted on the body of Argentine society; society itself was torn apart by the disappearance and murder of thousands of its citizens. The Argentine community was damaged insofar as attachments with loved ones were severed. This has resulted in a collective trauma that has involved 'a blow to the basic tissues of social life that damages the bonds attaching people together and impairs the prevailing sense of communality’ (Erikson 1995: 187). 
Kai Erikson (1995) suggests that trauma has a social dimension, and can create community. For many survivors of Argentina's clandestine detention centres, and the families of desaparecidos and murdered individuals, feeling different from others after experiencing a trauma has become a kind of calling and has drawn individuals together who are similarly affected (Erikson 1995). While the numbness and dislocation shared by traumatised individuals mean that relating to each other can be painful and difficult, they can still be shared as a source of communality and shared identity (Erikson 1995).

However, while trauma can engender a sense of community between individuals and groups, it can also damage the texture of a community (Erikson 1995). Dori Laub and Nanette Auerhahn (1989) write that the link between individuals is predicated on the possibility and expectation of empathy. However, when individuals' vital needs either go unheeded or are ignored by others, those individuals lose the expectation that their needs will in some way be met (Laub \& Auerhahn 1989). As the individual no longer feels they have anyone on whom they can count, the link between the self and the 'other' is obliterated by a failure of empathy (Laub \& Auerhahn 1989). A failure of empathy indicates a failure in an individual's interpersonal environment: the message one sends out is not responded to by another (Laub \& Auerhahn 1989). For example, Barbara was told by government agencies that she did not have the right to claim assistance as a victim of the military dictatorship because her father was declared a fascist. Barbara told me:

I went to speak with forensic psychologists who were reconstructing cases. I wanted to know how they operated, how they worked out to which group the murdered belonged. And they told me, no, your father was a fascist. A lot of doors closed for me because of the ideology of my father.

The lack of receptivity for her trauma has made Barbara feel as if she is not regarded as a citizen with equal rights within Argentine society. Barbara feels there is no understanding for her experience of loss, and feels desperately alone as a result. Barbara does not feel she is able to engage within her environment interpersonally, and as such is unable to elicit a sense of mutuality. She is left feeling that she has nobody within the government or human rights organisations on whom she can count.

In Argentina, considerable social damage has been produced by the significant absence of empathy for the grief of others. This has denied both groups of women what they desire: the acknowledgement and empathic engagement with their suffering by those 
individuals instrumental and directly responsible in causing their emotional pain (Ross 2003). When the women believe their memories have not been given the political, moral, social and legal recognition they feel they deserve within the public sphere of collective remembrance, affective alignment fails; this failure of affective alignment perpetuates the stalemate between members of antagonistic memorial cultures (Ahmed 2004a).

What this means for the women I interviewed is that the failure of empathy for the other group's grief destroys the possibility for communication between adversarial memorial cultures. The women's ideologically charged projections result in certain fixations 'that project onto others or deposit into others negative affects'; in turn, these can create the illusion of affects being 'located' in other individuals of ideologically opposed groups (Schwab 2010: 112). The circulation of negative affects can radically disturb people’s understanding of themselves, as well as their relations with others and the past (Probyn 2010). What is then produced is a lack of what Ahmed (2004a: 36) calls 'fellow feeling': the women's pain cannot be shared through empathy with others in different memory groups.

\section{Conclusion}

It becomes clear that we cannot possibly understand Argentine social or public life without understanding the transmission of affective memory. We cannot hope to understand the forces that are at play to keep such stigma and deep animosity in place decades after the end of the dictatorship. Affect is created as the women repetitively share their narratives of violence and loss in the public sphere. Affect is that which is said and that remains unsaid in the oral testimony encounter. It is that which can communicate and motivate overtly and publicly; but it is also an excess that remains unprocessed and misrecognised, evading consciousness yet provoking behaviour all the same.

In post-authoritarian contexts emerging from periods of mass violence, the notion of affect is particularly relevant to raising our consciousness of how individuals carry the legacy of surviving violence and how they continue living with their heart-breaking loss. Most crucially, I believe, the notion of affect makes us conscious of the vulnerability of others. Judith Butler (2003) critically asks, 'What makes for a grievable life?' She asserts that a process of differential grieving can lead to the marginalisation of groups that do not conform to the prevailing norm of the human (Butler 2009). These ungrievable groups are 
framed as never having been lives at all, and so are already lost from the living (Butler 2009). Perceived as threats to human life rather than as living people, such groups become targeted for marginalisation in order to 'protect the lives of the living' (Butler 2009: 31). Butler presents a connection between vulnerability, political recognition and the performative element of community by arguing that violence and the experience of loss are a part of us all: we all have some notion of what it is to lose somebody. She argues that grief can lay bare the 'thrall' in which our relations with others hold us; 'in ways that often interrupt the self-conscious account of ourselves we might try to provide, in ways that challenge the very notion of ourselves as autonomous and in control' (Butler 2004: 23).

Butler tells us that we need to critically evaluate and oppose such conditions that make some lives more vulnerable and more grievable than others: 'From where might a principle emerge by which we vow to protect others from the kinds of violence we have suffered, if not from an apprehension of a common human vulnerability?’ (Butler 2003: 30). We must acknowledge, however, what a mammoth task it is to recognise this 'common human vulnerability' to which Butler refers - to ask individuals who have been pushed to the limits of humanity themselves to see the vulnerability of those who have pushed them. When I think about how some of the women I interviewed struggle to find a way to keep living with their memories, I question whether we can ask any more of them.

However, there were moments when some of the women described moving into a different relationship to the pain they were suffering. Victoria Paz told me:

I quietly approached some families [of the disappeared] that I could trust so that they could explain to me and teach me about the violence they suffered... For my pain and the injustice that happened to my father to take its rightful place [in Argentina's collective memorial record], I had to find out the other side of the story. If not, then my story is partial and subjective. ${ }^{14}$

Victoria's comment reminds us that while affect can result in a negative attachment to others, it is in following the trails of affect, with the 'restlessness of its promise' and 'the relief of its continued mobilization' (Stewart 2010: 353), that we may find new relational possibilities and new, non-reductive ways of thinking about memory in a society recovering from violence and trauma.

\footnotetext{
${ }^{14}$ Interview with Victoria Paz, Buenos Aires, 12 July 2009.
} 


\section{Reference List}

Ahmed, S. 2000, Transformations: Thinking through Feminism. Routledge, New York.

Ahmed, S. 2004a, 'Collective Feelings: Or, the Impressions Left by Others,' Theory Culture Society, vol. 21, no. 2: 25-42.

2004b, The Cultural Politics of Emotion. Edinburgh University Press, Edinburgh.

Assmann, J. 2006, Religion and Cultural Memory: Ten Studies, trans. R. Livingstone. Stanford University Press, Stanford, CA.

Brennan, T. 2004, The Transmission of Affect. Cornell University Press, Ithaca \& New York.

Brysk, A. 1994, The Politics of Human Rights in Argentina: Protest, Chance, and Democratization. Stanford University Press: Stanford, CA.

Butler, J. 2003, 'Violence, Mourning, Politics,' Studies in Gender and Sexuality, vol. 4, no. 1: 9-37.

Butler, J. 2009, Frames of War: When is Life Grievable? Verso, London.

Calveiro, P. 2005, Politica y/o violencia: Una aproximación a la guerrilla de los años 70. GrupoEditorial Norma: Buenos Aires.

Comisión Nacional de Verdad y Reconciliación (CONADEP). 1986, Nunca más (Never Again). Informe de la Comisión Nacional sobre la Desaparición de Personas. Faber, London.

Deleuze, G. 1988, Spinoza, Practical Philosophy. City Lights Books, San Francisco.

Erikson, K. 1995, 'Notes on Trauma and Community,' in Trauma: Explorations in Memory, (ed.) C. Caruth. Johns Hopkins University Press, Baltimore, MD: 183-199.

Feitlowitz, M. 1998, A Lexicon of Terror: Argentina and the Legacies of Torture. Oxford University Press: New York.

Gibbs, A. 2010, 'After Affect: Sympathy, Synchrony, and Mimetic Communication,' in The Affect Theory Reader, (eds) M. Gregg \& G. J. Seigworth. Duke University Press, Durham, NC: 186-205.

Halbwachs, M. 1992, On Collective Memory, trans L.A. Coser. Chicago: University of Chicago Press.

Honneth, A. 1995, The Struggle for Recognition: The Moral Grammar of Social Conflicts. Polity Press, Cambridge, MA.

Hutchison, E. \& Bleiker, R. 2008, 'Emotional Reconciliation: Reconstituting Identity and Community after Trauma,' European Journal of Social Theory, vol. 11, no. 3: 385-403.

Jelin, E. 2003, State Repression and the Labors of Memory. University of Minnesota Press, Minneapolis, $\mathrm{MN}$.

Kaiser, S. 2005, Postmemories of Terror: A New Generation Copes with the Legacy of the 'Dirty War.' Palgrave Macmillan, New York.

Laub, D. \& Auerhahn, N. C. 1989, 'Failed Empathy-A Central Theme in the Survivor's Holocaust Experience,' Psychoanalytic Psychology, vol. 6, no. 4: 377-400.

Massumi, B. 1987, 'Notes on the Translation and Acknowledgements,' in A Thousand Plateaus, (eds) G. Deleuze \& F. Guattari. University of Minnesota Press, Minneapolis, MN.

Massumi, B. 2002, Parables for the Virtual: Movement, Affect, Sensation. Duke University Press, Durham, NC.

Merleau-Ponty, M. 1962, Phenomenology of Perception. Routledge \& Kegan Paul, London.

Misztal, B. A. 2004, 'The Sacralization of Memory,' European Journal of Social Theory, vol. 7, no. 1: 67-84.

Oliver, K. 2001, Witnessing: Beyond Recognition. University of Minnesota Press, Minneapolis, MN.

Paez, D., Basabe, N., \& Gonzalez, J. L. 1997, 'Social Processes and Collective Memory: A CrossCultural Approach to Remembering Political Events,' in Collective Memory of Political Events: Social Psychological Perspectives, (eds) J. Pennebaker, D. Paez \& B. Rimé. Lawrence Erlbaum, Mahwah, NJ: 223-226.

Passerini, L. 2003, 'Memories Between Silence and Oblivion,' in Contested Pasts: The Politics of Memory, (eds) K. Hodgkin \& S. Radstone. Routledge, London: 238-254.

Pennebaker, J.W. \& Banasik, B. L. 1997, 'On the Creation and Maintenance of Collective Memories: History as Social Psychology,’ in Collective Memory of Political Events: Social Psychological Perspectives, (eds) J. Pennebaker, D. Paez \& B. Rimé. Lawrence Erlbaum, Mahwah, NJ: 3-20.

Probyn, E. 2010, 'Writing Shame,' in The Affect Theory Reader, (eds) M. Gregg \& G. J. Seigworth. Duke University Press, Durham, NC: 71-92.

Rimé, B. \& Christophe, V. 1997, 'How Individual Emotional Episodes Feed Collective Memory,' in Collective Memory of Political Events: Social Psychological Perspectives, (eds) J. Pennebaker, D. Paez \& B. Rimé. Lawrence Erlbaum, Mahwah, NJ: 131-146.

Ross, F. 2003, 'Bearing Witness to Ripples of Pain,' in World Memory: Personal Trajectories in Global Time, (eds) J. Bennett \& R. Kennedy. Palgrave Macmillan, New York: 143-159.

Rothberg, M. 2009, Multidirectional Memory: Remembering the Holocaust in the Age of Decolonization. Stanford University Press, Stanford, CA. 
Schwab, G. 2010, Haunting Legacies: Violent Histories and Transgenerational Trauma. Columbia University Press: New York.

Shouse, E. 2005, 'Feeling, Emotion, Affect,' Media-Culture Journal, vol. 8, no. 6. Online, available: http://journal.media-culture.org.au/0512/03-shouse.php [Accessed 13 October 2013].

Stewart, K. 2010, ‘Afterword: Worlding Refrains.’ in The Affect Theory Reader, (eds) M. Gregg \& G. J. Seigworth. Duke University Press, Durham, NC: 339-354.

Stockwell, J. 2014, Reframing the Transitional Justice Paradigm: Women's Affective Memories in PostDictatorial Argentina. Springer Academic Publishing: New York.

Sosa, C. 2009, 'A Counter-Narrative of Argentine Mourning,' Theory, Culture and Society, vol. 26, no. 7-8: 250-262.

Traverso, A. 2010, 'Dictatorship Memories: Working through Trauma in Chilean Post-Dictatorship Documentary,' Continuum: Journal of Media \& Cultural Studies, vol. 24, no. 1: 179-191.

Tumarkin, M. 2009, 'Disturbing the Sound of Silence: Towards the Thick Vision of the Long Soviet Silence.’ Performance Paradigm, vol. 5, no. 2. Online, available:

http://www.performanceparadigm.net/journal/issue-52/articles/disturbing-the-sound-of-silencetowards-the-thick-vision-of-the-long-soviet-silence/ [Accessed March October 2013].

Watkins, M. 2010, 'Desiring Recognition, Accumulating Affect,' in The Affect Theory Reader, (eds) M. Gregg and G. J. Seigworth. Duke University Press, Durham, NC: 269-288. 